\section{Intron status and 3 '-end formation control cotranscriptional export of mRNA}

\author{
Elissa P. Lei and Pamela A. Silver ${ }^{1}$ \\ Department of Biological Chemistry and Molecular \\ Pharmacology, Harvard Medical School and Dana-Farber \\ Cancer Institute, Boston, Massachusetts 02115, USA
}

\begin{abstract}
Messenger RNA export factors are recruited to genes in a transcription-dependent manner. To ascertain the mechanism of this process, we show that RNA polymerase II transcription is sufficient to recruit the Saccharomyces cerevisiae hnRNP protein $\mathrm{Npl} 3$ to a gene independent of RNA sequence. In contrast, the cotranscriptional recruitment of the RNA-binding protein Yra1 is dependent on pre-mRNA processing. Yra1 associates with introns of intron-containing genes in a splicing-dependent manner. Conversely, Yra1 recruitment to genes without introns is not dependent on splicing. Finally, 3 '-end formation is required for Yra1 recruitment to genes regardless of intron status.
\end{abstract}

Received August 14, 2002; revised version accepted September 17, 2002.

In eukaryotes, mRNAs are transcribed and processed in the nucleus and exported to the cytoplasm. During transcription, mRNAs are bound by RNA-binding proteins that function in pre-mRNA processing steps such as capping, polyadenylation/cleavage, and splicing (for review, see Bentley 2002; Proudfoot et al. 2002). In addition, transcription promotes the recruitment of mRNA export factors to genes (Lei et al. 2001). The cotranscriptional recruitment of pre-mRNA processing and mRNA export factors has been suggested to be a mechanism for efficient production of fully processed and export-competent ribonucleoparticles (RNPs).

In Saccharomyces cerevisiae, $\mathrm{Npl} 3$ is an abundant protein that serves as a prototype for hnRNP function in mRNA export. Identified based on its ability to UVcross-link to poly(A) ${ }^{+}$RNA (Wilson et al. 1994), Npl3 is one of the major RNA-binding proteins in yeast and may function to ensure structural integrity of the RNP. Mutation of NPL3 results in accumulation of mRNA in the nucleus (Singleton et al. 1995; Lee et al. 1996). Furthermore, Npl3 shuttles between the nucleus and the cytoplasm, and its export is dependent on ongoing transcription by RNA polymerase II (Pol II; Lee et al. 1996). Npl3 interacts physically with Pol II and genetically with

[Keywords: Yral; Npl3; mRNA export; transcription; splicing; chromatin IP]

${ }^{1}$ Corresponding author.

E-MAIL pamela_silver@dfci.harvard.edu; FAX (617) 632-5103.

Article and publication are at http://www.genesdev.org/cgi/doi/10.1101/ gad.1032902.
TATA-binding protein (TBP) to promote mRNA export (Lei et al. 2001). For Npl3, cotranscriptional recruitment begins at an early stage of transcription, either at initiation or soon after elongation begins. Finally, Npl3 cotranscriptional recruitment is specific for Pol II-transcribed genes.

Nuclear export of mRNA also depends on the function of the RNA-binding protein Yral. Acting at a later stage of mRNA export than Npl3, Yral bridges the interaction between the RNP and the soluble mRNA export receptor heterodimer Mex67/Mtr2 located primarily at the nuclear pore complex (NPC; Santos-Rosa et al. 1998; Sträßer and Hurt 2000). The human homolog of Yral, Aly, is a component of the exon-exon junction complex (EJC) that is deposited on mRNAs as a result of splicing (Le Hir et al. 2000). Although there is not yet evidence of the existence of an EJC in yeast, both Aly and the nonsense-mediated decay factor Upf3 associate with the EJC and are conserved throughout eukaryotes (Le Hir et al. 2001). Aly promotes the export of both spliced and unspliced mRNAs (Zhou et al. 2000; Rodrigues et al. 2001), and interaction of Aly with the splicing factor UAP56 has been suggested to be a mechanism of recruitment of Aly to spliced mRNAs (Luo et al. 2001). Similarly, Yral interacts with the UAP56 yeast homolog Sub2 (Sträßer and Hurt 2001), which is also involved in splicing (Kistler and Guthrie 2001; Libri et al. 2001; Zhang and Green 2001). In turn, Sub2 and its human homolog recently have been shown to physically interact with the conserved THO complex of transcription elongation factors, which are required for proper mRNA export (Sträßer et al. 2002). In fact, Aly was originally isolated as a transcriptional coactivator (Bruhn et al. 1997).

Less well understood is how 3 '-end formation of mRNA contributes to its nuclear export. Disruption of cleavage/polyadenylation by either cis- or trans-acting mutations results in nuclear accumulation of transcripts (Eckner et al. 1991; Long et al. 1995; Huang and Carmichael 1996; Brodsky and Silver 2000). Furthermore, these defects cause accumulation of transcripts at a focus that may be near the site of transcription (Hilleren et al. 2001; Jensen et al. 2001). One candidate for a mediator of 3'end formation stimulated mRNA export is the hnRNP protein Hrp1, which is a component of the cleavage complex CF I (Kessler et al. 1997). Hrpl interacts genetically with $\mathrm{Npl3}$ and is required for nuclear export of mRNA (Henry et al. 1996; Brodsky and Silver 2000).

Messenger RNA export factors are recruited to genes in a transcription-dependent manner to increase the efficiency of mRNA export (Lei et al. 2001). However, the mechanism of this cotranscriptional recruitment is not known. Here we show that Pol II transcription is sufficient to cotranscriptionally recruit $\mathrm{Npl3}$ to an RNA. In contrast, Yral associates with intron-containing genes preferentially at introns in a splicing-dependent manner. Moreover, the splicing factor Sub2 associates with genes in a pattern identical to that of Yra1. However, SUB2 is not required for Yral recruitment to genes without introns. Additionally, 3'-end formation is required for Yra1 recruitment to all genes tested regardless of intron status. We present a model for cotranscriptional pre-mRNA processing-dependent packaging of mRNAs for nuclear export. 


\section{Results and Discussion}

The specificity of $\mathrm{Npl} 3$ recruitment to mRNA could be achieved through interaction between Npl3 and RNA or by interaction of Npl3 with the Pol II transcription machinery. To test these two possibilities, we examined whether Npl3 can be recruited to a gene that is not normally transcribed by Pol II using a strain (YJV100) that expresses the 35S rDNA under the control of the inducible GAL7 Pol II promoter (GAL7 $7_{\text {pro }}-35 S$ rDNA; Venema et al. 1995). This fusion gene is integrated into the rDNA locus in multiple copies, and the strain is deleted for RNA polymerase I ( $\Delta$ rpa135) so that all rRNA transcription is driven by Pol II. Cells were grown in galactosecontaining media to stimulate transcription of galactosedependent genes, including the Pol II-driven rRNA, or were transcriptionally repressed by addition of glucose for $1 \mathrm{~h}$. We performed chromatin immunoprecipitations of Npl3 from chromatin of an average size of $\sim 200$ bases using $\alpha-\mathrm{Npl} 3$ antibodies. Quantitative PCR was performed using primer sets that span the galactose-dependent GAL10 gene, the GAL7 $7_{\text {pro }}-35 S$ rDNA fusion gene, or an intergenic nontranscribed region to determine the amount of DNA associated with Npl3 (Fig. 1A).

$\mathrm{Npl} 3$ associates with the GAL7 $7_{\text {pro }}-35 S$ rDNA fusion gene only when transcribed by Pol II. In cells grown in galactose, $\mathrm{Npl3}$ associates strongly with the coding sequence of GAL10, and this association is reduced 10-fold when cells are glucose-repressed, similar to previous results (Fig. 1B, lanes 1,2; Lei et al. 2001). Association of $\mathrm{Npl3}$ with the GAL7 pro $-35 S$ rDNA is approximately twofold higher than the nontranscribed intergenic region in cells grown in galactose (Fig. 1B, lanes 3-6, white bars). Upon glucose repression, $\mathrm{Npl} 3$ association with the $G A L 7_{\text {pro }}-35 S$ rDNA is decreased to background levels (Fig. 1B, lanes 3-6, gray bars). Chromatin immunoprecipitations using an antibody against Pol II (8WG16) show a similar pattern of association with GAL10 and the $G A L 7_{\text {pro }}-35 S$ rDNA (data not shown). In wild-type cells, Npl3 does not associate with Pol I-transcribed 35S rDNA (data not shown). These results indicate that Pol II transcription is sufficient for Npl3 cotranscriptional recruitment independent of RNA sequence.

In cells expressing the GAL7 $7_{\text {pro }}-35 S$ rDNA fusion gene, Npl3 is redistributed to the nucleolus. In wild-type cells, Npl3 localizes to a region of the nucleus that is adjacent to the crescent-shaped nucleolus, denoted by Nop1 staining, as previously described (Fig. 1C, panels a-c; Flach et al. 1994). When grown in galactose, cells expressing the $G A L 7_{\text {pro }}-35 S$ rDNA possess nucleoli that appear as a single focus that is adjacent but clearly distinct from the nucleoplasm as determined by comparison of Nop1 localization and DAPI staining (Fig. 1C, e; data not shown). In these cells, Npl3 staining is visible in the nucleoplasm as in wild type but also extends to a small adjacent region. In this area there is significant overlap of the Npl3 and Nop1 signals as indicated by orange to yellow signal in the overlay (Fig. $1 \mathrm{C}$, $\mathrm{d}-\mathrm{f}$, arrows). Taken together, these results indicate that Pol II transcription is sufficient for $\mathrm{Npl} 3$ cotranscriptional recruitment.

Unlike Npl3, Yral is not recruited to the $G A L 7_{\text {pro }}-35 S$ $r D N A$. Epitope-tagged Yral-myc was immunoprecipitated using $\alpha$-myc antibody (9E11), and the amount of DNA associated was quantitated. In cells grown in galactose, Yra1-myc associates strongly with the 3' but not the $5^{\prime}$ end of the GAL10 coding sequence compared with the nontranscribed intergenic region, and this association decreases $>20$-fold upon glucose repression, similar to previous results (Fig. 1D, lanes 1,2,6; Lei et al. 2001). In contrast, Yra1-myc association is not above background levels for the $5^{\prime}$, middle, or $3^{\prime}$ regions of the GAL7 $7_{\text {pro }}-35 S$ rDNA even under transcriptionally repressing conditions (Fig. 1D, lanes 3-6). Therefore, Pol II transcription is not sufficient for Yral cotranscriptional recruitment. A possible explanation for the lack of Yra1 recruitment to this gene is that a specific binding site for Yral may not be present in the 35S rRNA. Alternately,

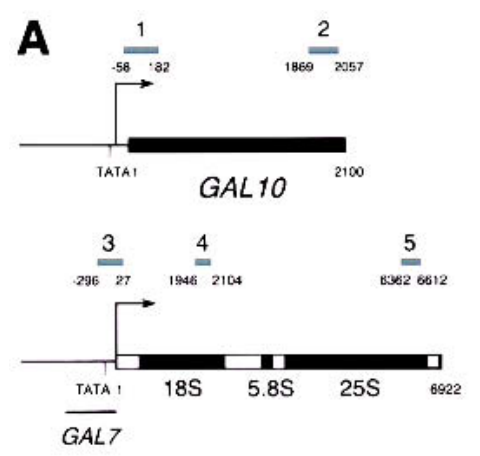

GAL7pro-35S rDNA

$6=$ intergenic region
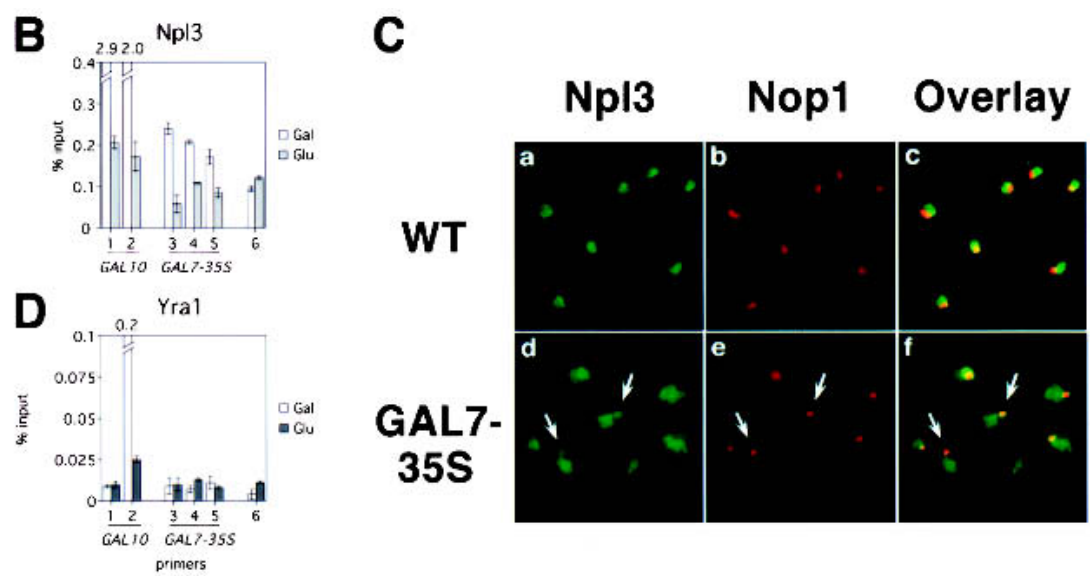

Figure 1. Pol II transcription is sufficient for Npl3 but not Yral cotranscriptional recruitment. (A) Diagram of $G A L 10$ and $G A L 7$ pro $-35 S$ rDNA. Primer sets 1 and 2 span the $5^{\prime}$ and $3^{\prime}$ coding sequence of $G A L 10$, respectively. Primer set 3 is specific for the $G A L 7$ pro $-35 S r D N A$ fusion. Primer sets 4 and 5 are directed to the $18 S$ and $25 S$ rDNA, respectively, recognizing the fusion gene as well as endogenous rDNA. (For GAL10, $\mathrm{ATG}=+1$; for $G A L 7_{\text {pro }}-35 S$ rDNA, 5' ETS $=+1$.) Primer set 6 spans a nontranscribed intergenic region. $(B)$ Quantitation of Npl3-associated DNA using primer sets indicated in $A$. Raw values are expressed as a percentage of input for cells grown at $30^{\circ} \mathrm{C}$ in media containing $1 \%$ raffinose/1\% galactose (white) and repressed for $1 \mathrm{~h}$ in $2 \%$ glucose (gray). Error bars are shown for a single experiment. Numerical values are shown above broken bars, which extend beyond the upper limit of the graph. (C) Colocalization of Npl3 and Nopl in wild-type (WT, $a-c)$ and $G A L 7$ pro $-35 S$ rDNA-expressing (GAL7-35S, $d-f)$ cells. Indirect immunofluorescence with polyclonal antibodies to Npl3 (a, $d$ ), monoclonal antibody to Nop1 $(b, e)$, and overlay $(c, f)$ are shown. Arrows point to the region of colocalization in $G A L 7$ pro $-35 S$ rDNA-expressing cells. $(D)$ Quantitation of Yral-myc-associated DNA using primer sets indicated in $A$. 
because the $35 \mathrm{~S}$ rRNA undergoes a series of processing steps that is entirely distinct from that of mRNA, some pre-mRNA processing steps may be a requirement for Yra1 recruitment.

To test whether splicing affects mRNA export factor cotranscriptional recruitment, we first tested whether recruitment is affected by the presence of an intron. We performed chromatin immunoprecipitations using as reporters three genes with different intron statuses (Fig. 2A). PMA1 is a gene without an intron, and ACT1, like the majority of intron-containing genes in S. cerevisiae, contains a single intron that is situated close to the transcription initiation site, resulting in a short $5^{\prime}$ exon. For $D B P 2$ and a handful of intron-containing genes, a single intron is located in the middle of the gene to produce a large $5^{\prime}$ exon of $>1 \mathrm{~kb}$. We predicted that if an EJC deposited by splicing exists in $S$. cerevisiae, it would be able to form on DBP2 but not ACT1 because a short $5^{\prime}$ exon is not capable of supporting EJC formation (Le Hir et al. 2001). As shown previously, Yra1-myc preferentially associates with the $3^{\prime}$ end of the intronless PMA1 gene more than fivefold compared with its $5^{\prime}$ end (Fig. 2B, center, lanes 1,2; Lei et al. 2001). Likewise, Yra1-myc association with $A C T 1$ is higher at the $3^{\prime}$ end; however, the difference between the $3^{\prime}$ and $5^{\prime}$ ends is less than twofold, and overall levels of ACT1 association are considerably closer to background than PMA1 (Fig. 2B, center, lanes $1-4,9)$. In contrast, Yral-myc association is biased clearly to the intron of $D B P 2$, peaking at the intron at least twofold higher than the first and second exons, suggesting the existence of an EJC (Fig. 2B, center, lanes 5-9). It remains a possibility that an EJC or equivalent in $S$. cerevisiae is deposited cotranscriptionally on the ACT1 transcript but may be indetectable by this assay because of the proximity of the intron to the transcription start site. Notably, the characteristic 3' bias of Yra1 is absent on $D B P 2$, indicating that Yral associates differently with genes depending on intron status.

Sub2 is cotranscriptionally recruited in a manner similar to Yral to genes with and without introns. Sub2-HA was immunoprecipitated from chromatin using an $\alpha$-HA antibody (12CA5), and the amount of DNA associated was quantitated. Consistent with the finding that Yra1 and Sub2 interact directly (Sträßer and Hurt 2001), the pattern of Sub2-HA association with PMA1, ACT1, and $D B P 2$ is essentially identical to that of Yral (Fig. 2B, right, lanes 1-9). In addition, Sub2-HA is recruited strongly to the middle and 3 ' end of the galactose-inducible gene GAL10 under transcriptionally active conditions comparable to Yra1, indicating that Sub2 recruitment to a gene is transcription-dependent (data not shown; Lei et al. 2001). Like Yra1, Sub2 is recruited to genes with and without introns, consistent with the result that SUB2 is required for the nuclear export of spliced and intronless mRNAs (Lei et al. 2001; Sträßer and Hurt 2001). In contrast to Yral and Sub2, Npl3 association with PMA1 and ACT1 is evenly distributed (Fig. 2B, left, lanes 1-4). For DBP2, Npl3 association is strongest at the $5^{\prime}$ end and tapers toward the $3^{\prime}$ end of the coding sequence similar to other genes tested (Fig. 2B, left, lanes 5-9; Lei et al. 2001). To reinforce our conclusions regarding intron status, we also tested the RPL30 and NOG2 genes, which display similar intron positions to $A C T 1$ and $D B P 2$, respectively, and found their behavior to be consistent (data not shown). Therefore, the presence and possibly the position of an intron affects Yral and Sub2 but not Npl3 cotranscriptional recruitment.

To determine whether splicing is required for mRNA export factor recruitment to genes, we examined cotranscriptional recruitment of $\mathrm{Npl} 3$ and Yral in the trans-acting splicing mutants prp5-1 and sub2-85. Mutations in both genes cause defects in early steps of spliceosome formation (Lustig et al. 1986; Kistler and Guthrie 2001; Zhang and Green 2001). Compared with wild type, prp5-1 mutants display normal recruitment of Npl3 to PMA1 and ACT1, although association with the second exon of ACT1 is increased by twofold (Fig. 3A, left, lanes 1-4, white and gray bars). However, Npl3 does not associate with $D B P 2$ significantly above background in prp5-1 cells (Fig. 3A, left, lanes 5-9, white and gray bars). Similarly, in sub2-85 cells, Npl3 is not recruited to $D B P 2$ but is increased up to 1.5 -fold at PMA1 and ACT1 (Fig. 3A, left, lanes 1-9, white and black bars), showing that the requirement for splicing is specific for $D B P 2$.

Splicing is also required for Yral recruitment to $D B P 2$ but not PMA1 or ACT1. In comparison with wild type, Yral is recruited normally to PMA1 and ACT1 in the
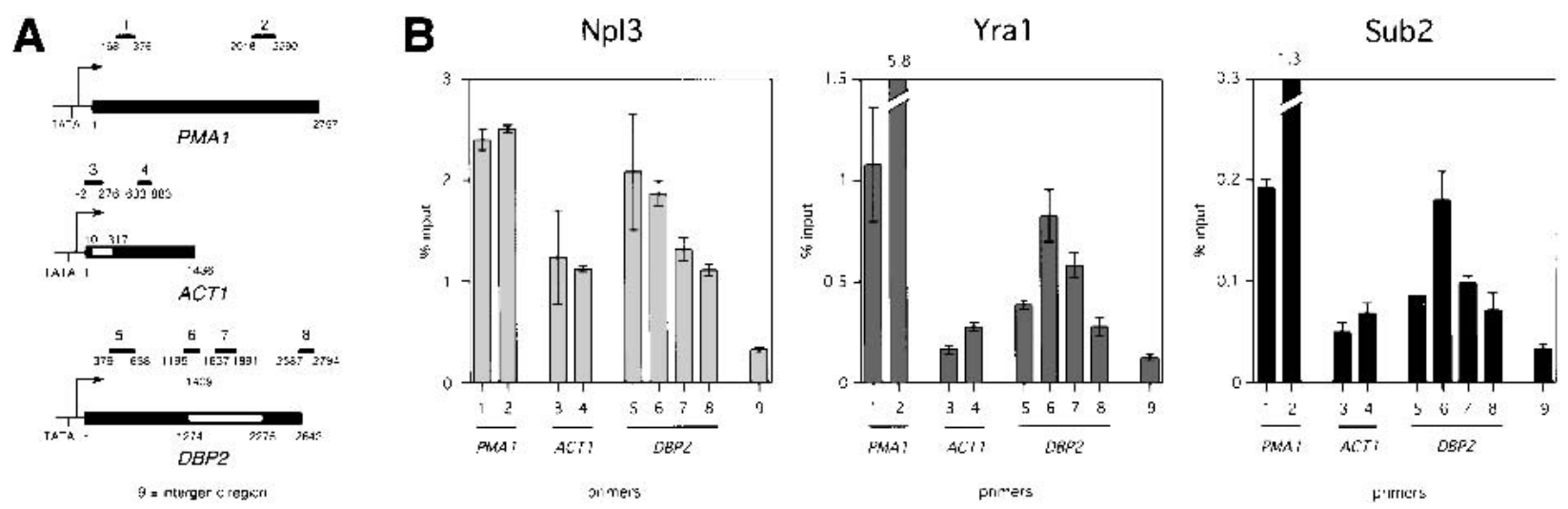

Figure 2. Effects of intron status on mRNA export factor cotranscriptional recruitment. $(A)$ Diagram of $P M A 1, A C T 1$, and $D B P 2$. Primer sets 1 and 2 span the $5^{\prime}$ and $3^{\prime}$ coding sequence, respectively, of $P M A 1$. Primer sets 3 and 4 span the intron and second exon, respectively, of $A C T 1$. Primer sets 5, 6, 7, and 8 span the first exon, $5^{\prime}$-exon-intron junction, intron, and second exon, respectively of $D B P 2(A T G=+1)$. Primer set 9 spans a nontranscribed intergenic region. $(B)$ Quantitation of Npl3- (left), Yra1-myc- (center), and Sub2-HA-associated (right) DNA using primer sets indicated in $A$. Raw values are expressed as a percentage of input for cells grown in YPD at $30^{\circ} \mathrm{C}$. Error bars are shown for a single experiment. Numerical values are shown above broken bars, which extend beyond the upper limit of the graph. 

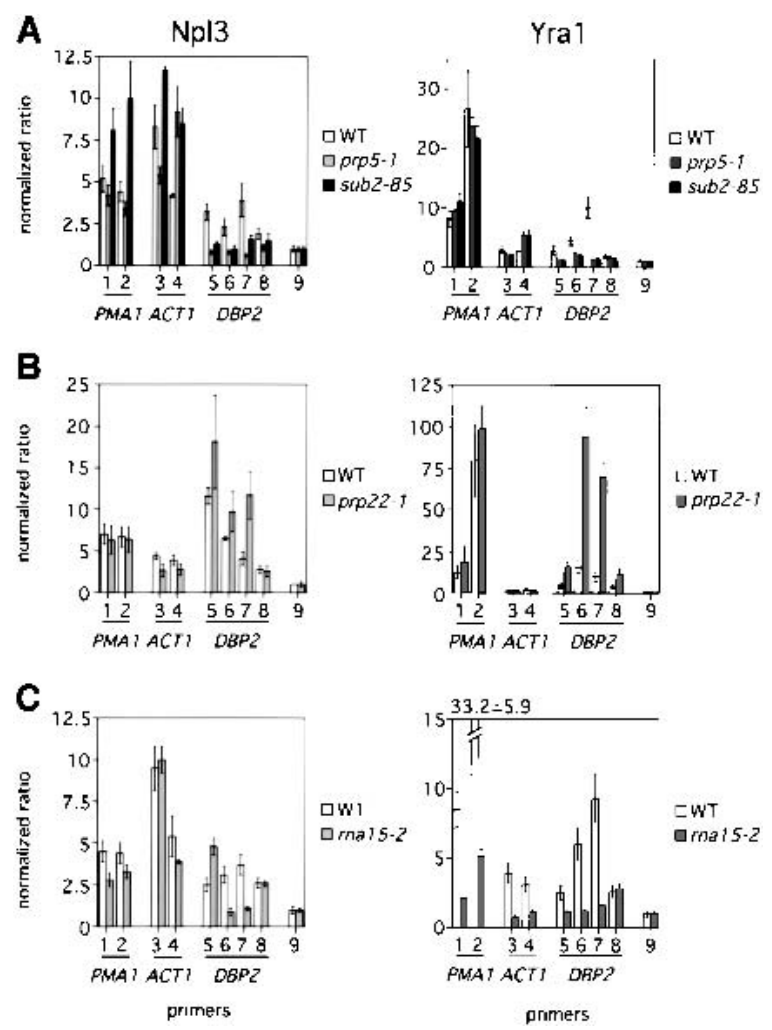

Figure 3. Mutants in splicing and $3^{\prime}$-end formation affect mRNA export factor cotranscriptional recruitment. (A) Quantitation of Npl3- (left) and Yra1-myc-associated (right) DNA using primer sets indicated in Figure 2A from wild-type (white), prp5-1 (gray), and sub2-85 (black) cells. Values are normalized to the intergenic region, which is arbitrarily set to 1 . Error is shown for a single experiment. Cells were grown at $25^{\circ} \mathrm{C}$ and shifted to $37^{\circ} \mathrm{C}$ for $30 \mathrm{~min}$. (B) Quantitation of Npl3- (left) and Yral-myc-associated (right) DNA using the primer sets indicated in Figure 2A from wild-type (white) and prp22-1 (gray) cells. Values are normalized to the intergenic region. Cells were grown at $25^{\circ} \mathrm{C}$ and shifted to $37^{\circ} \mathrm{C}$ for $2 \mathrm{~h}$. (C) Quantitation of Npl3- (left) and Yral-myc-associated (right) DNA using the primer sets indicated in Figure 2A from wild-type (white) and rna15-2 (gray) cells. Values are normalized to the intergenic region. Cells were grown at $25^{\circ} \mathrm{C}$ and shifted to $37^{\circ} \mathrm{C}$ for $30 \mathrm{~min}$.

prp5-1 and sub2-85 mutant strains (Fig. 3A, right, lanes 1-4). In contrast, Yral does not associate with $D B P 2$ above background levels in either mutant strain (Fig. 3A, right, lanes 5-9). Because sub2-85 and prp5-1 mutants behave very similarly in our cotranscriptional recruitment assays, we conclude that the function of SUB2 in recruitment of export factors is the same as that of a splicing factor. Furthermore, SUB2 is required for export of unspliced mRNAs (Sträßer and Hurt 2001) but does not affect mRNA export factor cotranscriptional recruitment to genes without introns; therefore, Sub2 must play a role in mRNA export that does not involve Yral recruitment.

To further test the hypothesis that splicing may be required for export factor recruitment, we performed the converse experiment of slowing mRNA release from the spliceosome and monitoring the association of export factors with genes. In comparison with wild type, Npl3 recruitment to PMA1 and ACT1 is unchanged in prp22-1 cells, which are defective at a late step of splicing (Fig. 3B, left, lanes 1-4; Company et al. 1991). However, Npl3 association with the intron of DBP2 is increased 1.5-fold to twofold in prp22-1 cells compared with wild type (Fig. 3B, left, lanes 5-9). Similarly, Yral recruitment to PMA1 and $A C T 1$ is not altered (Fig. 3B, right, lanes 1-4). In sharp contrast, Yral recruitment is increased approximately threefold over the first and second exons of $D B P 2$ and is enriched more than sixfold over the DBP2 intron (Fig. 3B, right, lanes 5-9). Importantly, Pol II association with DBP2 is not increased in the prp22-1 mutant, indicating that export factor accumulation at the gene is not simply a result of increased transcription /data not shown). Therefore, slowed kinetics of release of mRNA from the spliceosome causes accumulation of mRNA export factors at the site of $D B P 2$ transcription. Our results show that cotranscriptional splicing promotes the recruitment of export factors to at least some intron-containing genes, perhaps dependent on intron position.

Because 3 '-end formation is generally required for mRNA export (Eckner et al. 1991; Long et al. 1995; Huang and Carmichael 1996; Brodsky and Silver 2000), we reasoned that there may be a requirement for cleavage/polyadenylation in the cotranscriptional recruitment of mRNA export factors. Therefore, we examined the effects of export factor recruitment in the 3 '-cleavage mutant, rna15-2. In comparison with wild type, Npl3 recruitment to PMA1 and ACT1 is unchanged in rna15-2 cells (Fig. 3C, left, lanes 1-4). Despite changes in the profile of Npl3 recruitment, Npl3 is cotranscriptionally recruited to DBP2 (Fig. 3C, left, lanes 5-9). In contrast, overall levels of Yral recruitment to PMA1, ACT1, and $D B P 2$ are reduced dramatically in the rna15-2 mutant (Fig. 3C, right, lanes 1-9). In addition to mRNA export defects, 3'-end formation mutants display an apparent accumulation of mRNA that may be near the site of transcription (Hilleren et al. 2001; Jensen et al. 2001). Although the nature of the accumulated RNA is unknown, given the results presented here, we predict that Yral may not be bound to this pool of RNA, leaving it export-incompetent. These results show that 3 '-end formation is required for Yral but not Npl3 recruitment to all genes regardless of intron status.

Here we show that pre-mRNA processing stimulates the cotranscriptional recruitment of mRNA export factors to promote mRNA export. Specifically, Yral is preferentially recruited to certain intron-containing genes dependent on splicing and generally recruited to all genes dependent on $3^{\prime}$-end formation. Taken together, our results suggest a model of cotranscriptional premRNA processing stimulated packaging of mRNAs for export (Fig. 4). Although our findings indicate a requirement for both splicing and polyadenylation, given the extensive interplay among the various pre-mRNA processing steps, either splicing or polyadenylation could play a predominant role in this process. In contrast to Yra1, Npl3 can be recruited to a gene through interaction with the transcription machinery independent of the sequence of the RNA, indicating that specific pre-mRNA processing events are not absolutely required for Npl3 recruitment. More broadly, these results suggest that the transcription machinery can dictate the specificity of protein-RNA interactions.

Conversely, we find that Pol II transcription is not sufficient for Yral recruitment. It has been proposed recently that the inessential THO complex of transcription elongation factors can recruit Sub2 and, by association, Yral to genes (Sträßer et al. 2002). Because it is 


\section{A no intron}

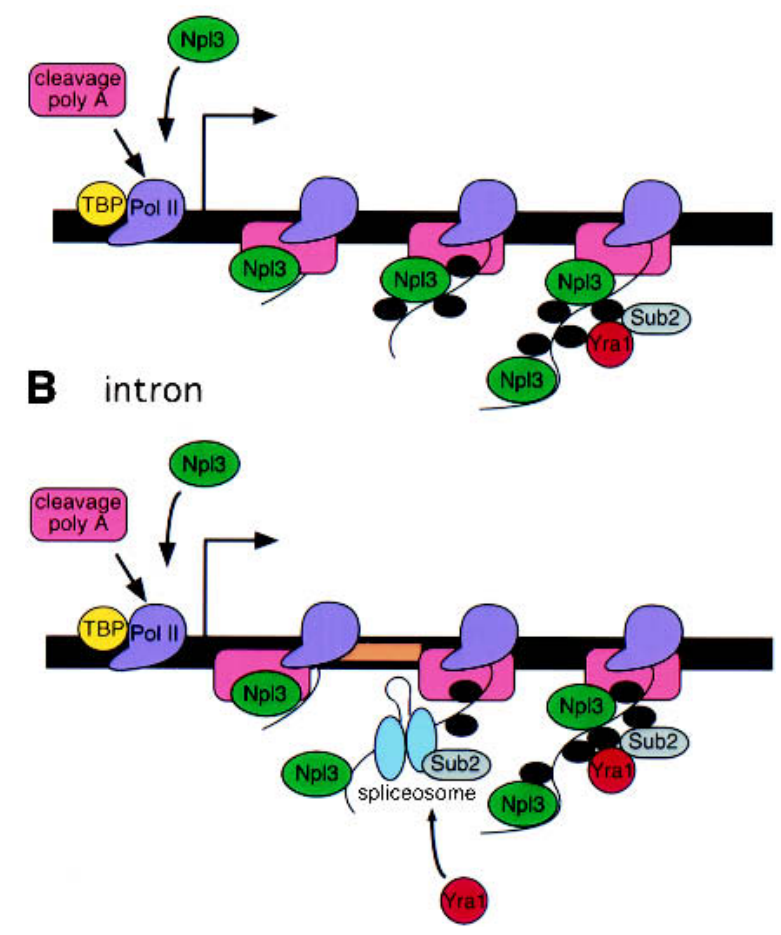

Figure 4. Packaging model for coordinated transcription, splicing, 3 '-end formation, and mRNA export. $(A)$ In the absence of an intron, $\mathrm{Npl3}$ (green) and 3'-end formation factors (pink) are recruited by the transcription machinery to genes at an early stage of transcription (Dantonel et al. 1997; Lei et al. 2001; Licatalosi et al. 2002). Shown are TATA-binding protein (TBP, yellow) and RNA polymerase II (Pol II, purple). Npl3 is transferred to the growing RNA and is joined by pre-mRNA processing and export factors (black). Sub2 (gray) and Yra1 (red) are recruited to the RNA at a later stage of transcription, dependent on the presence or activity of $3^{\prime}$-end formation factors and perhaps other RNA-binding proteins. $(B)$ When an intron (peach) is present sufficiently far from the site of transcription initiation, the spliceosome (blue) including Sub2 is recruited to the site of transcription and preferentially recruits Yral. Yral recruitment is dependent on splicing, 3 '-end formation, and perhaps the presence of other RNA-binding proteins.

present in substoichiometric amounts compared with Pol II, the THO complex may be required for only a subset of genes or under certain growth conditions. Interestingly, it has been shown that splicing factors can stimulate transcription elongation, suggesting that splicing can cause a transcriptional feedback (Fong and Zhou 2001). Therefore, we examined Pol II recruitment in all chromatin immunoprecipitation experiments but did not find a strong correlation of export factor and Pol II recruitment (data not shown). Hence, a clear transcriptional feedback could not be detected in these experiments. Furthermore, the ability to separate export factor association from that of Pol II in a mutant that affects pre-mRNA processing (Fig. 3B, DBP2) indicates that the chromatin immunoprecipitation assay is capable of detecting RNA-dependent protein association with genes.

Nuclear export of mRNA serves as a regulatory step to ensure that only properly processed mRNAs are translated (for review, see Lei and Silver 2002). It has been shown that polyadenylation is required for mRNA ex- port, but the mechanism remains unknown. Furthermore, microinjection studies have shown that mRNAs that undergo splicing are exported more efficiently than unspliced mRNAs (Luo and Reed 1999). Subsequent studies showed that a stimulatory effect of splicing on mRNA export is not observed for all spliced mRNAs (Le Hir et al. 2001; Rodrigues et al. 2001). Although the work of Luo and Reed (1999) is provocative, these studies bypass transcription, offering a simplified view of mRNA export. Our studies go beyond these findings and provide evidence that splicing and 3 '-end formation enhance mRNA export by stimulating the recruitment of mRNA export factors to the RNA as it is being transcribed.

\section{Materials and methods}

Chromatin immunoprecipitations were performed as described previously (Lei et al. 2001). Each experiment was performed at least twice. Quantitation and error are shown for a single experiment consisting of at least three independent measurements of a single immunoprecipitation extrapolated from a standard curve of at least five dilutions of input known to be in the linear range of PCR. For $18 \mathrm{~S}$ and $25 \mathrm{~S}$ rDNA primers 18-20 cycles of PCR were performed, but for all others, 26-30 cycles were performed. For normalized experiments in Figure 3, the propagated error of the ratio of the percentage input determined for a given primer set to that of the intergenic region is shown for a single experiment. Western blotting was performed to confirm consistent protein levels and IP efficiency in each strain. Wild-type (PSY2408), prp5-1 (PSY 2692), sub2-85 (PSY2670), prp22-1 (PSY 2562), and rna15-2 (PSY2822) strains deleted for the genomic copy of YRA1 and expressing pNOPMYCA1L-YRA1 (Lei et al. 2001) were used for mutant analysis. Sub2-HA (PSY2673) was created by C-terminal integration of three copies of the HA epitope followed by the kanMX6 marker into PSY580 using a method previously described (Longtine et al. 1998). Wild-type (PSY2408) or Sub2-HA were used for steady-state analysis. Control chromatin immunoprecipitations using 12CA5 $(\alpha-\mathrm{HA})$ and 9E11 $(\alpha-\mathrm{myc})$ in untagged strains yielded signal $<0.007 \%$ input. For YJV100 experiments, a plasmid encoding Yra1-myc (pPS2701) was used and was produced by subcloning an SacII/XhoI fragment of pNOPMYCA1L-YRA1 into pRS313 (Sikorski and Hieter 1989). Indirect immunofluorescence was performed as described previously (Krebber et al. 1999) using mouse monoclonal $\alpha$-Nop1 at 1:2500 and polyclonal $\alpha$-Npl3 at 1:5000 and rhodamine-donkey $\alpha$-mouse and FITCdonkey $\alpha$-rabbit, respectively. Wild-type (PSY580) or YJV100 cells were grown in YP containing $1 \%$ raffinose $/ 1 \%$ galactose at $30^{\circ} \mathrm{C}$.

\section{Acknowledgments}

We thank C. Guthrie, E. Hurt, F. Lacroute, and H. Raué for providing strains. We are indebted to M. Ares, C. Stern, and M. Yu for critical reading of the manuscript and members of the Silver laboratory for discussion. E.P.L. was supported by grants from the NCI and the Ryan Foundation. This work was supported by grants from the NIH to P.A.S

The publication costs of this article were defrayed in part by payment of page charges. This article must therefore be hereby marked "advertisement" in accordance with 18 USC section 1734 solely to indicate this fact.

\section{References}

Bentley, D. 2002. The mRNA assembly line: Transcription and processing machines in the same factory. Curr. Opin. Cell Biol. 14: 336-342.

Brodsky, A.S. and Silver, P.A. 2000. Pre-mRNA processing factors are required for nuclear export. RNA 6: 1737-1749.

Bruhn, L., Munnerlyn, A., and Grosschedl, R. 1997. ALY, a contextdependent coactivator of LEF-1 and AML-1, is required for TCR $\alpha$ enhancer function. Genes \& Dev. 11: 640-653.

Company, M., Arenas, J., and Abelson, J. 1991. Requirement of the RNA helicase-like protein PRP22 for release of messenger RNA from spliceosomes. Nature 349: 487-493.

Dantonel, J.C., Murthy, K.G., Manley, J.L., and Tora, L. 1997. Transcription factor TFIID recruits factor CPSF for formation of $3^{\prime}$ end of mRNA. Nature 389: 399-402.

Eckner, R., Ellmeier, W., and Birnstiel, M.L. 1991. Mature mRNA 3' end 
formation stimulates RNA export from the nucleus. $E M B O J$. 10: 3513-3522.

Flach, J., Bossie, M., Vogel, J., Corbett, A., Jinks, T., Willins, D.A., and Silver, P.A. 1994. A yeast RNA-binding protein shuttles between the nucleus and the cytoplasm. Mol. Cell. Biol. 14: 8399-8407.

Fong, Y.W. and Zhou, Q. 2001. Stimulatory effect of splicing factors on transcriptional elongation. Nature 414: 929-933.

Henry, M., Borland, C.Z., Bossie, M., and Silver, P.A. 1996. Potential RNA binding proteins in Saccharomyces cerevisiae identified as suppressors of temperature-sensitive mutations in NPL3. Genetics 142: $103-115$.

Hilleren, P., McCarthy, T., Rosbash, M., Parker, R., and Jensen, T.H 2001. Quality control of mRNA 3'-end processing is linked to the nuclear exosome. Nature 413: 538-542.

Huang, Y. and Carmichael, G.C. 1996. Role of polyadenylation in nucleocytoplasmic transport of mRNA. Mol. Cell. Biol. 16: 1534-1542.

Jensen, T.H., Patricio, K., McCarthy, T., and Rosbash, M. 2001. A block to mRNA nuclear export in $S$. cerevisiae leads to hyperadenylation of transcripts that accumulate at the site of transcription. Mol. Cell 7: 887-898

Kessler, M.M., Henry, M.F., Shen, E., Zhao, J., Gross, S., Silver, P.A., and Moore, C.L. 1997. Hrp1, a sequence-specific RNA-binding protein that shuttles between the nucleus and the cytoplasm, is required for mRNA 3'-end formation in yeast. Genes \& Dev. 11: 2545-2556.

Kistler, A.L. and Guthrie, C. 2001. Deletion of MUD2, the yeast homolog of U2AF65, can bypass the requirement for sub2, an essential spliceosomal ATPase. Genes \& Dev. 15: 42-49.

Krebber, H., Taura, T., Lee, M.S., and Silver, P.A. 1999. Uncoupling of the hnRNP Npl3p from mRNAs during the stress-induced block in mRNA export. Genes \& Dev. 13: 1994-2004.

Lee, M.S., Henry, M., and Silver, P.A. 1996. A protein that shuttles between the nucleus and the cytoplasm is an important mediator of RNA export. Genes \& Dev. 10: 1233-1246.

Le Hir, H., Izaurralde, E., Maquat, L.E., and Moore, M.J. 2000. The spliceosome deposits multiple proteins 20-24 nucleotides upstream of mRNA exon-exon junctions. EMBO J. 19: 6860-6869.

Le Hir, H., Gatfield, D., Izaurralde, E., and Moore, M.J. 2001. The exonexon junction complex provides a binding platform for factors involved in mRNA export and nonsense-mediated mRNA decay. EMBO J. 20: 4987-4997.

Lei, E.P. and Silver, P.A. 2002. Protein and RNA export from the nucleus. Dev. Cell 2: 261-272.

Lei, E.P., Krebber, H., and Silver, P.A. 2001. Messenger RNAs are recruited for nuclear export during transcription. Genes \& Dev. 15: 1771-1782.

Libri, D., Graziani, N., Saguez, C., and Boulay, J. 2001. Multiple roles for the yeast SUB2/yUAP56 gene in splicing. Genes \& Dev. 15: 36-41.

Licatalosi, D.D., Geiger, G., Minet, M., Schroeder, S., Cilli, K., McNeil, J.B., and Bentley, D.L. 2002. Functional interaction of yeast premRNA 3' end processing factors with RNA polymerase II. Mol. Cell 9: 1101-1111.

Long, R.M., Elliott, D.J., Stutz, F., Rosbash, M., and Singer, R.H. 1995 Spatial consequences of defective processing of specific yeast mRNAs revealed by fluorescent in situ hybridization. RNA 1: 1071-1078.

Longtine, M.S., McKenzie III, A., Demarini, D.J., Shah, N.G., Wach, A., Brachat, A., Philippsen, P., and Pringle, J.R. 1998. Additional modules for versatile and economical PCR-based gene deletion and modification in Saccharomyces cerevisiae. Yeast 14: 953-961.

Luo, M.J. and Reed, R. 1999. Splicing is required for rapid and efficient mRNA export in metazoans. Proc. Natl. Acad. Sci. 96: 14937-14942.

Luo, M.L., Zhou, Z., Magni, K., Christoforides, C., Rappsilber, J., Mann, M., and Reed, R. 2001. Pre-mRNA splicing and mRNA export linked by direct interactions between UAP56 and Aly. Nature 413: 644-647.

Lustig, A.J., Lin, R.J., and Abelson, J. 1986. The yeast RNA gene products are essential for mRNA splicing in vitro. Cell 47: 953-963.

Proudfoot, N.J., Furger, A., and Dye, M.J. 2002. Integrating mRNA processing with transcription. Cell 108: 501-512.

Rodrigues, J.P., Rode, M., Gatfield, D., Blencowe, B., Carmo-Fonseca, M., and Izaurralde, E. 2001. REF proteins mediate the export of spliced and unspliced mRNAs from the nucleus. Proc. Natl. Acad. Sci. 98: 1030-1035.

Santos-Rosa, H., Moreno, H., Simos, G., Segref, A., Fahrenkrog, B., Panté, N., and Hurt, E. 1998. Nuclear mRNA export requires complex for- mation between Mex67p and Mtr2p at the nuclear pores. Mol. Cell. Biol. 18: 6826-6838.

Sikorski, R.S. and Hieter, P. 1989. A system of shuttle vectors and yeast host strains designed for efficient manipulation of DNA in Saccharomyces cerevisiae. Genetics 122: 19-27.

Singleton, D.R., Chen, S., Hitomi, M., Kumagai, C., and Tartakoff, A.M. 1995. A yeast protein that bidirectionally affects nucleocytoplasmic transport. J. Cell Sci. 108: 265-272.

Sträßer, K. and Hurt, E. 2000. Yralp, a conserved nuclear RNA-binding protein, interacts directly with Mex67p and is required for mRNA export. EMBO I. 19: 410-420.

. 2001. Splicing factor Sub2p is required for nuclear mRNA export through its interaction with Yralp. Nature 413: 648-652.

Sträßer, K., Masuda, S., Mason, P., Pfannstiel, J., Oppizzi, M., RodriguezNavarro, S., Rondon, A.G., Aguilera, A., Struhl, K., Reed, R., et al. 2002. TREX is a conserved complex coupling transcription with messenger RNA export. Nature 417: 304-308.

Venema, J., Dirks-Mulder, A., Faber, A.W., and Raue, H.A. 1995. Development and application of an in vivo system to study yeast ribosomal RNA biogenesis and function. Yeast 11: 145-156.

Wilson, S.M., Datar, K.V., Paddy, M.R., Swedlow, J.R., and Swanson, M.S 1994. Characterization of nuclear polyadenylated RNA-binding proteins in Saccharomyces cerevisiae. J. Cell Biol. 127: 1173-1184.

Zhang, M. and Green, M.R. 2001. Identification and characterization of yUAP/Sub2p, a yeast homolog of the essential human pre-mRNA splicing factor hUAP56. Genes \& Dev. 15: 30-35.

Zhou, Z., Luo, M.J., Straesser, K., Katahira, J., Hurt, E., and Reed, R. 2000. The protein Aly links pre-messenger-RNA splicing to nuclear export in metazoans. Nature 407: 401-405. 


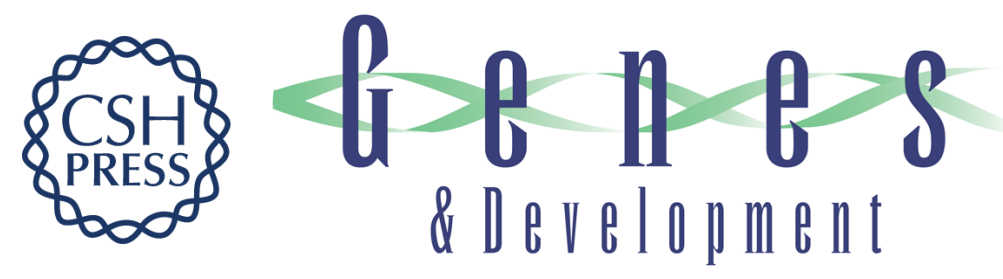

\section{Intron status and $3^{\prime}$-end formation control cotranscriptional export of mRNA}

Elissa P. Lei and Pamela A. Silver

Genes Dev. 2002, 16:

Access the most recent version at doi:10.1101/gad.1032902

References This article cites 39 articles, 22 of which can be accessed free at: http://genesdev.cshlp.org/content/16/21/2761.full.html\#ref-list-1

License

Email Alerting

Receive free email alerts when new articles cite this article - sign up in the box at the top Service right corner of the article or click here.

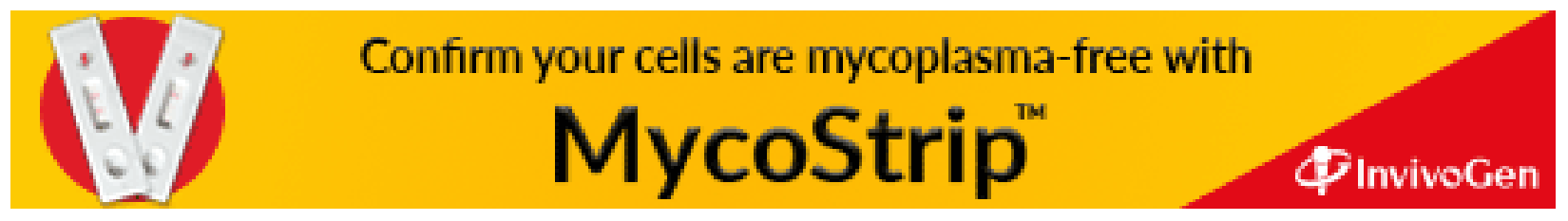

